\title{
PENGARUH MODEL PEMBELAJARAN INKUIRI TERBIMBING TERHADAP KEMAMPUAN BERPIKIR KRITIS PESERTA DIDIK
}

\author{
Lia Nurmayani*, Aris Doyan, Ni Nyoman Sri Putu Verawati \\ Program Studi Pendidikan Fisika, Universitas Mataram \\ *Email: liyaanurmayani@gmail.com
}

\begin{abstract}
This study aims to determine the effect of guided inquiry learning model toward critical thinking skills of students. This type of research is quasi experiment with non-equivalent group design. Sampling using purposive sampling technique, so that obtained class XI MIA 1 as experiment class and class XI MIA 2 as control class. The research instrument is a essay test of 5 questions that have been tested for validity, reliability, level of difficulty, and different power of problems. The learning data of the two classes is normally distributed. Based on the homogenity data obtained both homogeneous. Data were analyzed by MANOVA test. Result of data analysis show significance 0,021 if determined the level of significance 0,05 then 0,021<0,05. Based on these facts it can be concluded that there is influence of guided inquiry learning model toward critical thinking skills of students.
\end{abstract}

Keywords: guided inquiry learning model, critical thinking skills.

\section{PENDAHULUAN}

Fisika merupakan salah satu cabang dari IPA, dan merupakan ilmu yang berkembang melalui langkah-langkah observasi, perumusan masalah, penyusunan hipotesis, pengujian hipotesis melalui eksperimen, penarikan kesimpulan, serta penemuan teori dan konsep. Hakikat fisika adalah ilmu pengetahuan yang mempelajari gejala-gejala melalui serangkaian proses yang dikenal dengan proses ilmiah yang dibangun atas dasar sikap ilmiah dan hasilnya terwujud sebagai produk ilmiah yang tersusun atas tiga komponen terpenting berupa konsep, prinsip, dan teori yang berlaku secara universal.

Pada umumnya, peserta didik mengalami kesulitan dalam mempelajari fisika. Hal ini merupakan masalah dalam proses belajar. Masalah belajar yang dialami oleh peserta didik akan menghambat kelancaran dalam proses belajarnya. Kondisi ini dapat berkenaan dengan keadaan dirinya yaitu berupa kelemahan-kelemahan yang dimiliki dan dapat juga dipengaruhi dari lingkungan yang tidak menguntungkan bagi dirinya. Permasalahan dalam belajar tidak hanya dialami oleh peserta didik yang berkemampuan rendah saja tetapi juga dialami oleh peserta didik yang pandai.

Berdasarkan hasil observasi yang telah dilakukan, di SMAN 6 Mataram khususnya di kelas XI, terdapat beberapa masalah dalam kegiatan pembelajaran antara lain pembelajaran yang masih bersifat teacher center, cara mengajar guru yang terkesan monoton bagi peserta didik karena kurang menggunakan model yang bervariasi dalam proses pembelajaran, peserta didik cenderung dituntut untuk mengasah aspek ingatan, tanpa diajak untuk berpikir, kurang melatih peserta didik untuk mengembangkan daya nalarnya dalam mengaplikasikan konsep-konsep yang telah dipelajari dalam kehidupan nyata sehingga kemampuan berpikir kritis peserta didik kurang dapat berkembang dengan baik.

Berpikir kritis dalam pembelajaran sangat diperlukan karena berpikir kritis merupakan modal bagi peserta didik untuk dapat mengembangkan pengetahuan secara luas. Kemampuan berpikir juga merupakan dasar dalam suatu proses pembelajaran. Pembelajaran dalam kurikulum 2013 peserta didik dituntut untuk mengembangkan kemampuan berpikir kritisnya, hal ini 
dijelaskan pada salah satu indikator pada Standar Kompetensi Lulusan (SKL) Kurikulum 2013 yaitu peserta didik dituntut untuk memiliki (melalui mengamati, menanya, mencoba, mengolah, menyaji, menalar, dan mencipta) kemampuan berpikir dan bertindak yang efektif dan kreatif dalam ranah abstrak dan konkret sebagai pengembangan dari yang dipelajari disekolah secara mandiri (sesuai dengan bakat dan minatnya).

Menurut Ennis (2011:1) Berpikir kritis adalah kemampuan berpikir reflektif yang berfokus pada pola pengambilan keputusan tentang apa yang harus diyakini dan harus dilakukan. Tujuan melatihkan kemampuan berpikir kritis kepada peserta didik adalah untuk menyiapkan peserta didik menjadi seorang pemikir kritis, mampu memecahkan masalah, dan menjadi pemikir independen, sehingga mereka dapat menghadapi kehidupan, mengatasi setiap masalah yang dihadapi, dan membuat keputusan dengan tepat dan bertanggung jawab.

Model pembelajaran inkuiri terbimbing merupakan salah satu model untuk mengembangkan kemampuan berpikir kritis peserta didik dalam pembelajaran fisika. Model pembelajaran ini menuntut peserta didik untuk aktif selama proses pembelajaran sekaligus mendorong peserta didik untuk mengoptimalkan keterampilan dan kemampuannya (Yeritia, 2017:182). Inkuiri terbimbing merupakan suatu model pembelajaran yang melibatkan seluruh kemampuan peserta didik untuk mencari dan menyelidiki suatu permasalahan secara kritis, logis, dan analitis untuk mencari dan menemukan sendiri jawaban dari suatu permasalahan yang dipertanyakan dengan bimbingan guru dengan penuh percaya diri (Trianto, 2010:166). Melalui kegiatan ini, peserta didik dapat belajar untuk penyajian masalah, membuat atau menyajikan hipotesis, melakukan percobaan untuk memperoleh informasi atau data, mengumpulkan dan menganalisis data, dan membuat simpulan.

Model pembelajaran ini membuat peran guru tidak terlihat dominan, guru bertindak sebagai organisator dan fasilitator. Guru tidak memberitahukan konsep-konsep tetapi membimbing peserta didik menemukan konsep-konsep tersebut melalui kegiatan belajar, sehingga konsep yang didapat berdasarkan kegiatan dan pengalaman belajar tersebut akan selalu diingat peserta didik dalam waktu yang lama. Tahapan-tahapan model pembelajaran inkuiri terbimbing dapat mengakomodasi kegiatan-kegiatan yang mengarah pada peningkatan keterampilan berpikir kritis peserta didik.

Berdasarkan uraian di atas, perlu penelitian lebih lanjut tentang "Pengaruh Model Pembelajaran Inkuiri Terbimbing terhadap Kemampuan Berpikir Kritis Peserta Didik".

\section{METODE PENELITIAN}

Jenis penelitian adalah quasi eksperimen, dimana peneliti tidak memiliki keleluasaan untuk memanipulasi subjek, artinya random kelompok biasanya dipakai sebagai dasar untuk menetapkan sebagai kelompok perlakuan dan kontrol (Setyosari, 2015:149).

Desain penelitian yang diterapkan dalam penelitian ini adalah nonequivalent control group design. Desainnya dapat dilihat pada tabel di berikut ini.

Tabel 1. Desain Penelitian dengan Nonequivalent Control Group Design

\begin{tabular}{cccc}
\hline $\mathrm{O} 1$ & $\mathrm{X}$ & $\mathrm{O} 2$ & (eksperimen) \\
\hdashline $\mathrm{O} 3$ & $\mathrm{O} 4$ & (kontrol) \\
\hline \multicolumn{4}{c}{ Sumber: (Setyosari, 2015:211) }
\end{tabular}

Keterangan :

$\mathrm{O}_{1}=$ Kelas eksperimen sebelum diberikan perlakuan

$\mathrm{O}_{2}=$ Kelas eksperimen setelah diberikan perlakuan

$\mathrm{O}_{3}=$ Kelas kontrol sebelum diberikan perlakuan

$\mathrm{O}_{4}=$ Kelas kontrol setelah diberikan perlakuan

$\mathrm{X}=$ Perlakuan berupa model pembelajaran inkuiri terbimbing 
Penelitian ini dilakukan di SMAN 6 mataram Indonesia. Sampel dipilih secara purposive sampling. Sampel penelitian terdiri dari dua kelas yaitu XI MIA 1 sebagai kelas eksperimen dan XI MIA 2 sebagai kelas kontrol.

Tahap awal dari penelitian ini adalah memberikan pretest kepada peserta didik di kelas kontrol dan kelas eksperimen untuk mengetahui kemampuan awal peserta didik. Soal pretest yang diujikan berupa 10 soal uraian. Setelah diuji homogenitas dan normalitas, kedua kelas memiliki kemampuan awal homogen dan terdistribusi normal.

Kegiatan pembelajaran pada kelas eksperimen diberikan perlakuan berupa model pembelajaran inkuiri terbimbing dan kelas kontrol dengan pembelajaran yang diterapkan di sekolah. Setelah proses pembelajaran selesai, peserta didik diberikan posttest pada kedua kelas untuk mengetahui kemampuan akhir peserta didik setelah diberikan perlakuan. Setelah diuji homogenitas dan normalitas, kedua kelas memiliki kemampuan akhir homogen dan terdistribusi normal. Kemampuan berpikir kritis dianalisis yang mengacu pada persamaan:

$$
\text { nilai }=\frac{\text { skor yang diperoleh }}{\text { skor maksimal }} \times 100
$$

Adapun kategori kemampuan berpikir kritis dibedakan menjadi 4 kategori, yaitu sebagai berikut.

Tabel 2. Pedoman Kategori Berpikir Kritis

\begin{tabular}{cl}
\hline Skala Perolehan & Kategori \\
\hline $81,25<x \leq 100$ & Sangat Kritis \\
$62,50<x \leq 81,25$ & Kritis \\
$43,75<x \leq 62,50$ & Kurang Kritis \\
$25,00<x \leq 43,75$ & Sangat Kurang Kritis \\
\hline
\end{tabular}

(Dikutip dari Yuliati, 2011:24)

\section{HASIL DAN PEMBAHASAN}

Berdasarkan data kemampuan berpikir kritis peserta didik diperoleh nilai hasil tes awal dan tes akhir yang dilakukan pada kelas eksperimen dan kontrol. Adapun nilai yang diperoleh masing-masing kelas untuk setiap indikator dapat dilihat pada Gambar 1 berikut.

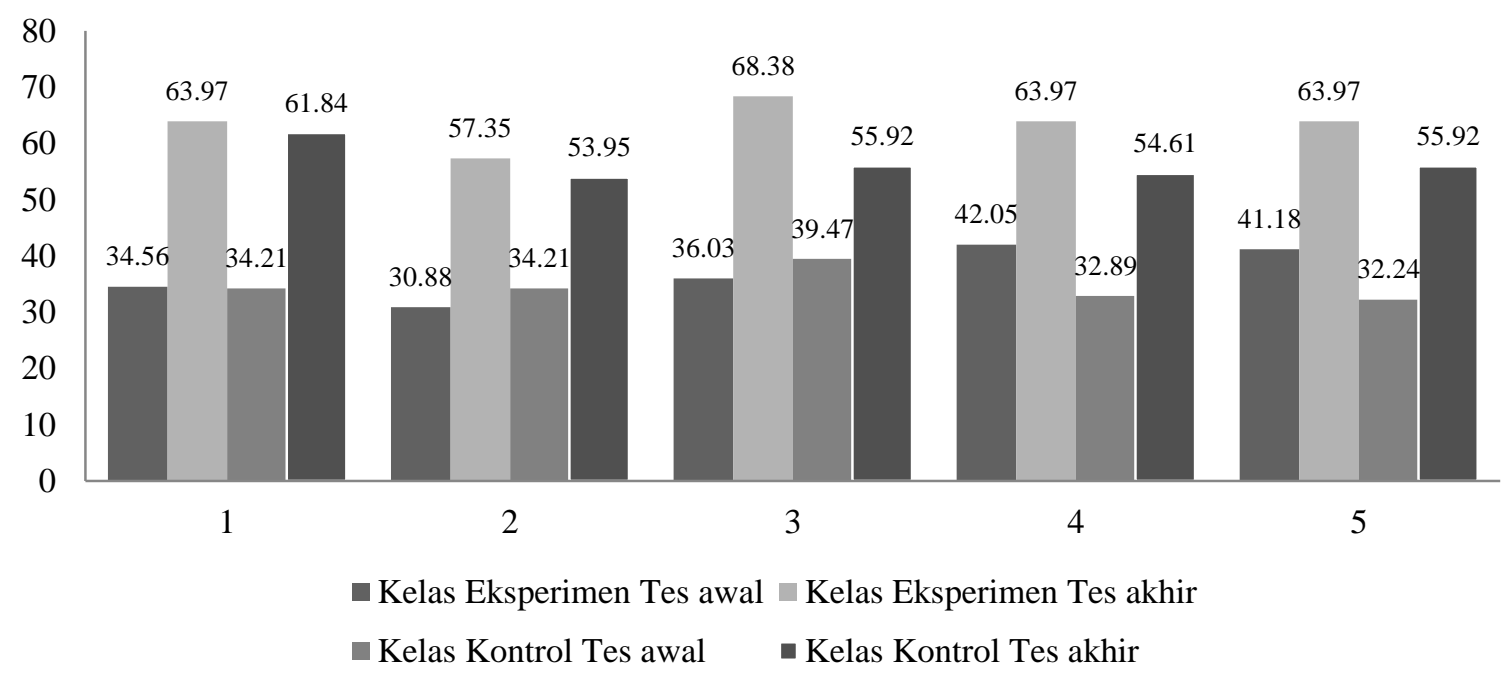

Gambar 1. Nilai Kelas Eksperimen dan Kelas Kontrol Masing-masing Indikator Kemampuan Berpikir Kritis

Keterangan:

(1) Klarifikasi dasar; (2) Keputusan dasar; (3) Inferensi; (4) Penjelasan lebih lanjut; (5) Menalar dan pengintegrasian. 
Berdasarkan data pada Gambar 1 diketahui bahwa indikator kemampuan berpikir kritis pertama, yaitu klarifikasi dasar. Pada kelas eksperimen setelah diberi perlakuan diperoleh nilai 63,97 dengan kategori kritis sedangkan untuk kelas kontrol diperoleh nilai 61,84 dengan kategori kurang kritis. Perbedaan hasil ini diakibatkan karena salah satu tahap model pembelajaran inkuiri terbimbing yang digunakan pada kelas eksperimen mendukung indikator tersebut. Tahap yang dimaksud adalah tahap menyajikan masalah. Fase ini peserta didik menyampaikan pendapat mengenai pengetahuan yang telah didapatkan sebelumnya. Melalui fase ini mereka dituntut untuk dapat menganalisis pendapat yang disampaikan dengan cara mengidentifikasi alasan mengenai konsep tertentu.

Pada indikator kemampuan berpikir kritis selanjutnya yaitu keputusan dasar. Pada kelas eksperimen setelah diberi perlakuan diperoleh nilai 57,35 dengan kategori kurang kritis sedangkan pada kelas kontrol diperoleh nilai 53,95 dengan kategori kurang kritis. Meskipun nilai klasikal yang diperoleh berbeda, namun keduanya masih dalam ketegori sama. Hal ini disebabkan karena pada kelas eksperimen masih belum aktif mencari informasi atau pengetahuan dicari sendiri dengan menggunakan berbagai sumber. Kekurangaktifan peserta didik ini menimbulkan kesulitan dalam menguasai konsep dan mengembangkan kemampuan berpikir kritisnya sehingga nilai peserta didik berkategori kurang kritis. Berbeda halnya dengan kelas kontrol yang terbiasa diberikan umpan terlebih dahulu oleh guru sebelum bekerja mandiri. Peserta didik sebaiknya dibiasakan untuk mandiri sehingga berpengaruh terhadap kemampuan untuk mengingat suatu konsep dalam jangka waktu yang lama, karena konsep yang diperoleh bukan dalam bentuk hafalan melainkan suatu pengetahuan yang didapatkan secara langsung dan tersimpan dalam memori jangka panjang.

Indikator ketiga yaitu inferensi merupakan indikator dengan nilai tertinggi pada kelas eksperimen diperoleh nilai 68,38 berkategori kritis. Lain halnya dengan kelas kontrol diperoleh nilai 55,92 dengan kategori kurang kritis. Nilai yang sangat tinggi pada kelas eksperimen terjadi karena pada setiap pertemuan yang telah dirancang dengan percobaan peserta didik diarahkan untuk melakukan inferensi. Inferensi yaitu membuat simpulan berdasarkan sesuatu yang dapat diukur dan diamati langsung. Berbeda halnya dengan kelas eksperimen, kelas kontrol tidak melakukan inferensi namun mereka melakukan kegiatan menyimpulkan pada akhir proses pembelajaran dengan diberi umpan terlebih dahulu oleh guru. Hal tersebut yang menyebabkan perbedaan nilai pada indikator ini.

Indikator yang keempat yakni penjelasan lebih lanjut pada kelas eksperimen dan kelas kontrol berturut-turut diperoleh nilai 63,97 dengan kategori kritis dan 54,61 yang berkategori kurang kritis. Pada indikator ini guru menantang dan memperluas pengetahuan yang telah didapatkan sebelumnya melalui pengalaman-pengalaman pengetahuan yang baru, mereka dapat menerapkan konsep yang telah dimiliki ke dalam konteks yang baru. Selain itu, pada indikator ini masingmasing individu juga dapat mendefinisikan istilah dan mempertimbangkan suatu definisi atau konsep dengan lebih jelas karena mereka menentukan sendiri asumsiasumsi untuk konsep atau definisi tersebut. Pada kelas kontrol, efektifitas peserta didik sebatas mendengarkan penjelasan dari guru, guru masih mendominasi dalam pembelajaran sehingga belum melibatkan peran aktif siswa secara keseluruhan ketika kegiatan belajar berlangsung. Hal inilah 
yang menyebabkan nilai pada kelas kontrol berkategori kurang kritis.

Indikator yang kelima yaitu menalar dan pengintegrasian. pada kelas eksperimen diperoleh nilai 63,97 dengan kategori kritis sedangkan untuk kelas kontrol bernilai 55,92 dengan kategori kurang kritis. Pada kelas eksperimen peserta didik dibiasakan belajar dengan penalaran yang diintegrasikan dengan pemikiran pengandaian karena dalam pembelajaran inkuiri terbimbing ditekankan untuk berpikir, berdiskusi dalam pemecahan masalah, dan kebiasaan berpikir yang mendorong peserta didik untuk melakukan eksplorasi sehingga menemukan konsep secara bermakna. Lain halnya dengan kelas kontrol, kurangnya penalaran yang diintegrasikan dengan pemikiran pengandaian pada proses diskusi sehingga membuat nilai peserta didik termasuk dalam kategori kurang kritis.

Berdasarkan data penelitian kemampuan berpikir kritis nilai rata-rata tes awal berpikir kritis peserta didik pada kelas eksperimen sebesar 36,76 berkategori sangat kurang kritis dan kelas kontrol sebesar 34,87 berkategori sangat kurang kritis. Setelah diberikan perlakuan pada kelas eksperimen menggunakan model pembelajaran inkuiri terbimbing dan kelas kontrol menggunakan pembelajaran konvensional terlihat perubahan yang signifikan terjadi pada kelas eksperimen. Tes akhir yang didapatkan kelas eksperimen sebesar 62,94 berada pada kategori kritis, sedangkan untuk kelas kontrol tes akhir yang didapatkan sebesar 56,84 masih berada pada kategori kurang kritis, seperti yang ditampilkan pada Gambar 2 berikut.

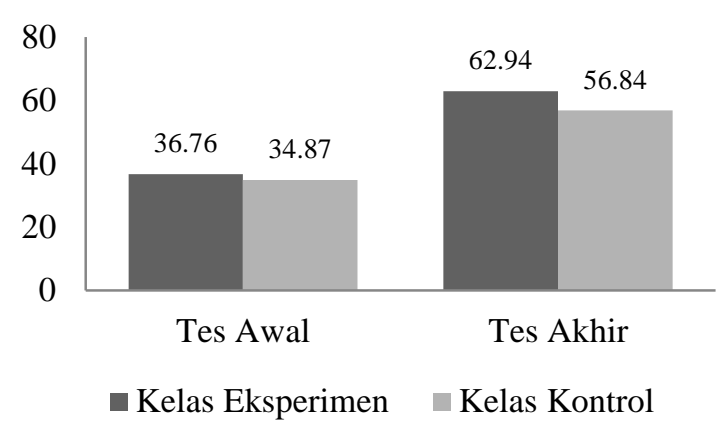

Gambar 2. Nilai rata-rata tes awal dan tes akhir kemampuan berpikir kritis kelas eksperimen dan kelas kontrol

$\begin{array}{ccc}\begin{array}{c}\text { Berdasarkan data tes awal } \\ \text { mengindikasikan }\end{array} \text { bahwa } & \text { proses }\end{array}$
pembelajaran yang berlangsung selama ini belum mampu meningkatkan kemampuan berpikir kritis karena aspek kognitif hanya ditekankan pada hasil bukan pada aspek proses yang melibatkan kemampuan berpikir kritis, sehingga kemampuan berpikir kritis yang dimiliki menjadi rendah, karena berpikir kritis terdiri dari tiga bagian yaitu pertama, mengajukan pertanyaan berkaitan dengan apa yang perlu ditanyakan, mengajukan pertanyaan yang baik, pertanyaan yang masuk ke inti permasalahan; kedua, usaha mencoba untuk menjawab pertanyaan melalui penalaran; dan ketiga kepercayaan pada hasil penalaran (Herayanti \& Habibi, 2015:78). Selain itu, penyebab lainnya dapat disebabkan karena kedua kelompok sampel belum memperoleh materi yang sesuai dengan jenjangnya melainkan hanya materi pengenalan usaha dan energi pada jenjang SMP. Nilai rata-rata tes awal kemampuan berpikir kritis ini kemudian dijadikan sebagai tolak ukur untuk melihat peningkatan kemampuan berpikir kritis peserta didik pada hasil tes akhir.

Nilai rata-rata tes akhir kelas eksperimen sebesar 62,94 berkategori kritis sedangkan kelas kontrol sebesar 56,84 berkategori kurang kritis. Peningkatan nilai rata-rata ini menunjukkan bahwa penerapan model pembelajaran inkuiri terbimbing berpengaruh terhadap kemampuan berpikir 
kritis. Berdasarkan hasil uji multivariat tersebut diperoleh taraf signifikansi sebesar $0,021<0,050$. Hal tersebut dapat terjadi karena model ini melibatkan peserta didik aktif baik secara fisik maupun mental dalam belajarnya. Peserta didik diajak berpikir mengenali masalah, menyelidiki untuk mencari jawaban terhadap masalah yang dihadapi sampai pada penyusunan kesimpulan. Hal tersebut membuat peserta didik terlatih untuk berpikir kritis.

Hal ini sesuai dengan apa yang dikemukakan oleh marjono, dkk (2012:21) bahwa pembelajaran dengan model inkuiri terbimbing menjadikan siswa belajar sebagai pemikir, bukan hanya sebagai penerima pasif pengetahuan. Pengenalan dan pemberian masalah yang relevan dengan kehidupan sehari-hari pada peserta didik, analitis untuk mencari dan menemukan sendiri jawaban dari suatu masalah yang dipertanyakanyang didasarkan atas observasi yang siswa lakukan, menjadikan siswa sebagai pembangun konsep secara ilmiah. Udayani, dkk (2014:6), bahwa kemampuan berpikir kritis akan berkembang jika selalu dihadapkan pada suatu permasalahan. Pembelajaran yang menuntut keterlibatan secara optimal dalam proses belajar dapat meningkatkan kemampuan berpikir kritis, Latifa (2017:66). Hal tersebut sejalan dengan Snyder \& Snyder (2008:94) yang menyebutkan bahwa lingkungan belajar yang melibatkan keaktifan dalam penyelidikan suatu informasi dan mengaplikasikan pengetahuan mereka meningkatkan kemampuan berpikir kritis. Hal ini dapat disimpulkan bahwa dengan menggunakan model pembelajaran inkuiri terbimbing dapat lebih meningkatkan kemampuan berpikir kritis peserta didik.

Berdasarkan hasil penelitian dapat disimpulkan bahwa ada pengaruh model pembelajaran inkuiri terbimbing terhadap kemampuan berpikir kritis peserta didik.

\section{REFERENSI}

Ennis, R. H. 2011. The Nature of Critical Thinking: An Outline of Critical Thinking Disposition and Abilities. University of Illinois. On line at http://faculty.education.illinois.edu/rh ennis/documents/TheNatureofCritical Thinking_51711_000.pdf [diakses tanggal 5 Juli 2017].

Herayanti, L., \& Habibi, H. (2015). Model Pembelajaran Berbasis Masalah Berbantuan Simulasi Komputer untuk Meningkatkan Keterampilan Berpikir Kritis Calon Guru Fisika. Jurnal Pendidikan Fisika dan Teknologi. 1(1), 61-66.

Latifa, B. R. A. 2017. Pengaruh Model Learning Cycle 5E (Engage, Explore, Explain, Elaboration, Evaluate) terhadap Kemampuan Berpikir Kritis Peserta Didik Kelas X MAN 1 Mataram. Jurnal Pendidikan Fisika dan Teknologi. 3(1):61-68.

Marjono, Sudarisman, S, \& Hapsari, D. P. 2012. Pengaruh Model Inkuiri Terbimbing Dengan Diagram V (Vee) dalam Pembelajaran Biologi terhadap Kemampuan Berpikir Kritis Dan Hasil Belajar Siswa. Pendidikan Biologi. Vol. 4(3):16-28.

Setyosari, P. 2015. Metode Penelitian Pendidikan dan Pengembangan. Jakarta: Kencana Prenadamedia Group.

Snyder, L.G. \& Snyder, M.J. 2008. Teaching Critical Thinking and Problem Solving Skills. The Delta Pi Epsilon Journal. 1(2), Spring/Summer, 2008: 90-99. Diakses tanggal 15 Maret 2018.

Trianto. 2010. Mendesain Model Pembelajaran Inovatif-Progresif. Jakarta: Kencana.

Udayani, P.A., Kusmariyatni, N., \& Wibawa, I.M.C. 2014. Pengaruh Model Siklus Belajar 5E Terhadap 
Kemampuan Berpikir Kritis IPA Siswa Kelas IV SD di Desa Kalibukbuk. e-Journal MIMBAR PGSD Universitas Pendidikan Ganesha Jurusan PGSD 1(2) : 1-10.

Yeritia, S., Rahayu, S. \& Wahyudi. 2017. Pengaruh Model Pembelajaran Inkuiri Terbimbing terhadap Penguasaan Konsep dan Kemampuan Berpikir Kritis Fisika Peserta Didik Kelas X SMAN 1 Kuripan Tahun Ajaran 2017/2018. Jurnal Pendidikan Fisika dan Teknologi. 3(2):181-187.

Yuliati. D.I., Yulianti, D., \& Khanafiyah, S. 2011. Pembelajaran Fisika Berbasis Hands On Activities Untuk Menumbuhkan Kemampuan Berpikir Kritis dan Meningkatkan Hasil Belajar Siswa SMP. Jurnal Pendidikan Fisika Indonesia.7: 23-27. 